\title{
IMMUNOLOGICAL RESPONSES TO PROTEIN, CARBOHYDRATE AND LIPID FRACTIONS OF NOCARDIA ASTEROIDES IN MICE
}

\author{
Rita Gupta, Vijaykumar Pancholi, V. K. VinayaK* and G. K. Khuller $\dagger$ \\ Departments of Biochemistry and *Experimental Medicine, Postgraduate Institute of \\ Medical Education and Research, Chandigarh-160012, India
}

\begin{abstract}
SUmmary. The protein, polysaccharide and phospholipid constituents of Nocardia asteroides have been partially purified and their immunogenicity studied in mice. Humoral and cellular immune responses were demonstrated against a crude cytoplasmic protein fraction (CPF). Two fractions of CPF were prepared on a Sephadex G-200 column; a high mol. wt fraction, fraction- $1\left(F_{1}\right)$ was capable of eliciting both types of immune responses, whereas fraction- $2\left(\mathrm{~F}_{2}\right)$ behaved more like a hapten. Phosphatides elicited only humoral responses whereas polysaccharides were non-immunogenic.
\end{abstract}

\section{INTRODUCTION}

Nocardiosis, a systemic bacterial disease caused mainly by Nocardia asteroides, is no longer rare and its pathogenesis is incompletely understood. The relative importance of cellular and humoral immunity in nocardiosis is not clearly defined (Beaman and Maslan, 1977; Curry, 1980; Beaman et al., 1982), although it has been suggested that cell-mediated immunity is more important than humoral. These studies appear to have been restricted to the response to whole nocardial cells which were either killed (Deem et al., 1982) or viable (Krick and Remington, 1975; Hiramine et al., 1981). Little attention has been given to the immune reactions induced by the proteins, polysaccharides and lipids of the nocardial cells. Because lymphocytes react with these components individually, it might be expected that the immune reactions that play a critical role in the pathogenesis of nocardiosis may be restricted to certain components of the nocardial cell rather than the whole cell. Hence, the present study was undertaken to investigate the immune responses elicited by constituents of $N$. asteroides in relation to the pathogenesis of the disease in mice.

\section{MATERIALS AND METHODS}

Bacterial strain. N. asteroides NCTC 8595 (equivalent to ATCC 14759) was obtained from the National Collection of Type Cultures, Collindale, U.K. and grown in Brain Heart Infusion Broth (BHI; HI-Media, Bombay, India) at $37^{\circ} \mathrm{C}$ for 7 days (stationary phase).

Animals. Swiss albino mice (outbred) of either sex weighing 18-20 g (4-5 weeks old) were used throughout and fed on a standard pellet diet (Hindustan Lever Ltd, Bombay, India) with water ad libitum.

Received 22 Nov. 1984; accepted 28 Jan. 1985.

† Requests for offprints should be sent to Dr G. K. Khuller. 
Preparation of protein components. A 7-day growth of $N$. asteroides in BHI broth was harvested, suspended in acetone and left overnight. The cells were filtered, freed from acetone by evaporation at room temperature and dried. The dried cells were suspended in normal saline in a $10 \%(\mathrm{w} / \mathrm{v})$ suspension. The cells were then sonicated at $60 \mathrm{~W}(20 \mathrm{KC} / \mathrm{s})$ intermittently in a "Sonifier" cell disrupter (Branson Sonic Power Co., Danbury, CT, USA) for $3 \mathrm{~h}$ in the cold. The unbroken cells were removed by centrifugation at $2800 \mathrm{~g}$ for $30 \mathrm{~min}$ and the supernate again centrifuged at $25000 \mathrm{~g}$ for $50 \mathrm{~min}$ in a refrigerated centrifuge (Sorvall RC-2B, Newton, CT, USA) to remove cell walls. The clear supernate was subjected to ammonium sulphate precipitation at $70 \%$ saturation. The precipitates were kept at $4^{\circ} \mathrm{C}$ overnight, dissolved in the

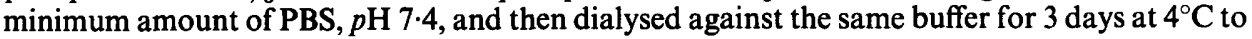
ensure complete removal of the ammonium sulphate as checked by the disappearance of white precipitates after addition of barium chloride to samples of the dialysate. This was denoted as crude protein fraction (CPF).

Four $\mathrm{ml}$ of the CPF (32 mg) was applied to a Sephadex G-200 (Pharmacia Fine Chemical, Uppsala, Sweden) column $(2 \times 80 \mathrm{~cm})$ which had been packed under a pressure of $16 \mathrm{~cm}$ of $\mathrm{Hg}$. The flow rate was adjusted to $20 \mathrm{ml} / \mathrm{h}$ and the proteins eluted with $0.01 \mathrm{M}$ phosphate buffer, $p \mathrm{H}$ 7.4. The eluants were collected in 4.2- $\mathrm{ml}$ fractions with an automatic fraction collector (LKB, Bromma, Sweden) and the absorbance read at $280 \mathrm{~nm}$ in a Beckman (Model-25) Spectrophotometer (USA). The elution volume was plotted against optical density and two peaks were obtained. The fractions under the two peaks were pooled and concentrated by dialysis against solid PEG (Polyethylene glycol, mol. wt 20 000; Sigma Chemicals, St Louis, MS, USA). These fractions were designated $F_{1}$ and $F_{2}$ respectively.

The fractions CPF, $F_{1}$ and $F_{2}$ were subjected to polyacrylamide gel electrophoresis (Davis, 1964) to check the complexity of their protein constituents at $5 \mathrm{~mA} / \mathrm{gel}$ for $2 \frac{1}{2} \mathrm{~h}$ in the presence of Tris-glycine buffer, $p \mathrm{H}$ 8.3. Protein estimation at each stage was done according to the method of Lowry et al. (1951).

Isolation and purification of polysaccharide fraction. N. asteroides was grown in $\mathrm{BHI}$ at $37^{\circ} \mathrm{C}$ for 7 days (stationary phase) and killed by autoclaving at $121^{\circ} \mathrm{C}$ for $20 \mathrm{~min}$. The cells were then harvested and suspended in a mixture of chloroform and methanol $(2: 1, \mathrm{v} / \mathrm{v})$ with constant stirring for $3 \mathrm{~h}$ to extract the lipids. The procedure was repeated twice and the filtrates pooled and used for the isolation of a lipid fraction. The defatted cells were used for the isolation of polysaccharide as described by Zamora et al. (1963). Briefly, the cells $(10 \mathrm{~g})$ were ground with 20 $\mathrm{g}$ of pyrex glass powder followed by treatment with $150 \mathrm{ml}$ of $3 \mathrm{M}$ potassium chloride $(\mathrm{KCl})$. The cell-free supernate obtained after centrifugation $(3500 \mathrm{~g}$ for $2 \mathrm{~h}$ ) of the suspension was added to 10 volumes of methanol and kept at $4{ }^{\circ} \mathrm{C}$ for $24 \mathrm{~h}$. The precipitates were centrifuged ( $1000 \mathrm{~g}$ for 10

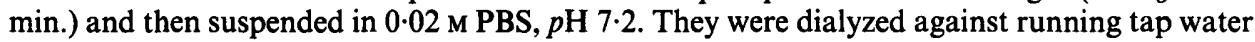
for $72 \mathrm{~h}$ and reprecipitated with 10 volumes of methanol. The precipitates were dried on acetone. The white precipitates were dissolved in $0.02 \mathrm{M}$ carbonate buffer, $p \mathrm{H} \mathrm{10.00}$. The soluble fraction was removed and designated as PS/I. The insoluble fraction was dissolved in $0.02 \mathrm{M}$ citrate

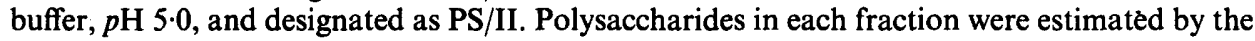
method of Dubois et al. (1956) with glucose as standard.

Purification of lipid fraction. Total phospholipids were used as an antigen. They were extracted according to the method of Folch et al. (1957). Autoclaved cells were extracted with chloroform:methanol $(2: 1, \mathrm{v}: \mathrm{v})$ twice or thrice and all the extracts were pooled. To this, one-fifth volume of $0.7 \%$ potassium chloride was added, mixed and kept overnight. The aqueous layer was removed and the remaining organic layer transferred to a round-bottomed flask and dried under vacuum. After two washings with chloroform-methanol-water $(16: 8: 1, \mathrm{v}: \mathrm{v}: \mathrm{v})$, the lipid was dried, dissolved in a known volume of chloroform and the phosphorus estimated (Bartlett, 1959). Neutral lipids were removed by repeated washings with acetone and the total phospholipids used for further work.

Identification and separation of individual phospholipids. Individual phospholipids were identified and separated by preparative thin-layer chromatography on silica gel-H (BDH, Glaxo Laboratories [India] Ltd, Bombay) plates by the method of Khuller (1976).

Immunisation schedule. Immunisation of mice was performed in a group of 20-30 animals with $\mathrm{CPF}, \mathrm{F}_{1}, \mathrm{~F}_{2}, \mathrm{PS} / \mathrm{I}, \mathrm{PS} / \mathrm{II}$ and phospholipids as described below. They were designated as group I to group VI respectively. 
Group Ia received three intraperitoneal injections each of CPF $50 \mu \mathrm{g}$ in $0 \cdot 1 \mathrm{ml}$, emulsified in an equal volume of Freund's incomplete adjuvant (FIA) at 5-day intervals. Group Ib was immunised with a single intraperitoneal injection of CPF $150 \mu \mathrm{g}$ in $0.1 \mathrm{ml}$ emulsified with FIA. Groups II and III received $150 \mu \mathrm{g}$ of $F_{1}$ and $F_{2}$ respectively, emulsified in FIA, in three equally divided doses, on days 0,5 and 10 .

Groups IV and V received PS I and PS II, respectively, by three different schedules: (i) a single intraperitoneal injection of $1 \mathrm{mg}$ of polysaccharide (PS I or PS II) emulsified in FIA; (ii) three subcutaneous injections $(0.2 \mathrm{ml})$, each of $100 \mu \mathrm{g}$, of each polysaccharide fraction with an equal amount of FIA at 5-day intervals; (iii) $50 \mu \mathrm{g}$ of polysaccharide $(0.1 \mathrm{ml})$ by intravenous injection in the tail vein on days 0 and 3 followed by subcutaneous injection of $50 \mu \mathrm{g}$ of polysaccharide and $50 \mu \mathrm{g}$ of methylated bovine serum albumin (MBSA) emulsified with FIA on day 6 and $50 \mu \mathrm{g}$ of polysaccharides intravenously on day 9 .

Group VI was immunised with three subcutaneous injections each of phospholipid ( $25 \mu \mathrm{g}$ lipid phosphorus) complexed with MBSA (Khuller and Subrahmanyam, 1971) and emulsified in FIA, at weekly intervals.

With each group a control group of animals (10 mice) was given in parallel, normal saline emulsified with or without FIA depending on the type of experiment in a corresponding schedule.

Measures of humoral immune response. The animals were bled before immunisation and samples of serum were stored at $-20^{\circ} \mathrm{C}$ for further use. In groups of 5 or 6 , the mice were bled to death and their spleens removed aseptically on days 7, 14, 21 and 28 after completion of immunisation. The sera were separated and stored at $-20^{\circ} \mathrm{C}$. The presence of specific or cross reacting antibodies or both were first detected by gel diffusion, immunoelectrophoresis and counter-current immunoelectrophoresis (CIE). A serum antibody titre for the animals immunised with the protein fractions was determined by indirect haemagglutination (IHA) as described by Herbert (1978), by use of $1.25 \%$ tanned sheep RBC coated with $88.5 \mu \mathrm{g}$ of protein/ml. Anti-phospholipid antibody titres were determined by kaolin agglutination (Takahashi, 1962) with $0.1 \% \mathrm{w} / \mathrm{v}$ standard kaolin suspension sensitised with $60 \mu \mathrm{g} / \mathrm{ml}$ of total phospholipids.

Measures of cell-mediated immune response (CMI). Aseptically-removed spleens were used to study cellular immune response by leukocyte migration inhibition (LMI) (Falk and Zabriskie, 1971). Briefly, the capillary tubes (length $75 \mathrm{~mm}$, internal diameter, $1.1 \mathrm{~mm}$ ) were filled with spleen-cell suspension ( $10^{7}$ viable leukocytes $\left./ \mathrm{ml}\right)$, centrifuged $(200 \mathrm{~g}$ for $10 \mathrm{~min})$ and cut at the cell-fluid interphase. The capillaries were placed in the leukocyte migration chambers (Laxbro, Pune, India) sealed with glass coverslips in the presence and absence of specific antigen (protein fractions $F_{1} 80 \mu \mathrm{g} / \mathrm{ml}, F_{2} 50 \mu \mathrm{g} / \mathrm{ml}$ ) polysaccharide (PS I $35 \mu \mathrm{g} / \mathrm{ml}$; PS II $60 \mu \mathrm{g} / \mathrm{ml}$ ) or total phospholipids $(100 \mu \mathrm{g} / \mathrm{ml})$ depending on the experiment. These antigen concentrations were the highest that gave no inhibition of migration with leukocytes from unimmunised animals. The percentage migration inhibition was calculated by the formula $(\mathrm{C}-\mathrm{T} / \mathrm{C}) \times 100$ where $\mathrm{C}$ is the migration in the absence of antigen and $\mathrm{T}$ is migration in the presence of the antigen.

\section{RESULTS}

The elution profile obtained showed two distinct peaks which were designated $F_{1}$ and $F_{2}$ (fig. 1). The percentages of protein distributed in and recovered from the two fractions are shown in the table; $87.75 \%$ of the protein applied was recovered in fractions $1\left(F_{1}\right)$ and $2\left(F_{2}\right)-32 \cdot 6 \%$ in $F_{1}$ and $55 \cdot 1 \%$ in $F_{2}$.

After polyacrylamide-gel electrophoresis, the CPF gave eight major bands (fig. 2a) whereas six and two bands were seen in $F_{1}$ and $F_{2}$ respectively (figs $2 b$ and $c$ ). $F_{1}$ was more complex than $F_{2}$. Concentrated $F_{1}$ was subfractionated into four fractions by preparative PAGE (fig. 2b).

Immune responses after immunisation with protein fractions. The sera obtained from the animals immunised with multiple injections of CPF formed multiple precipitation 


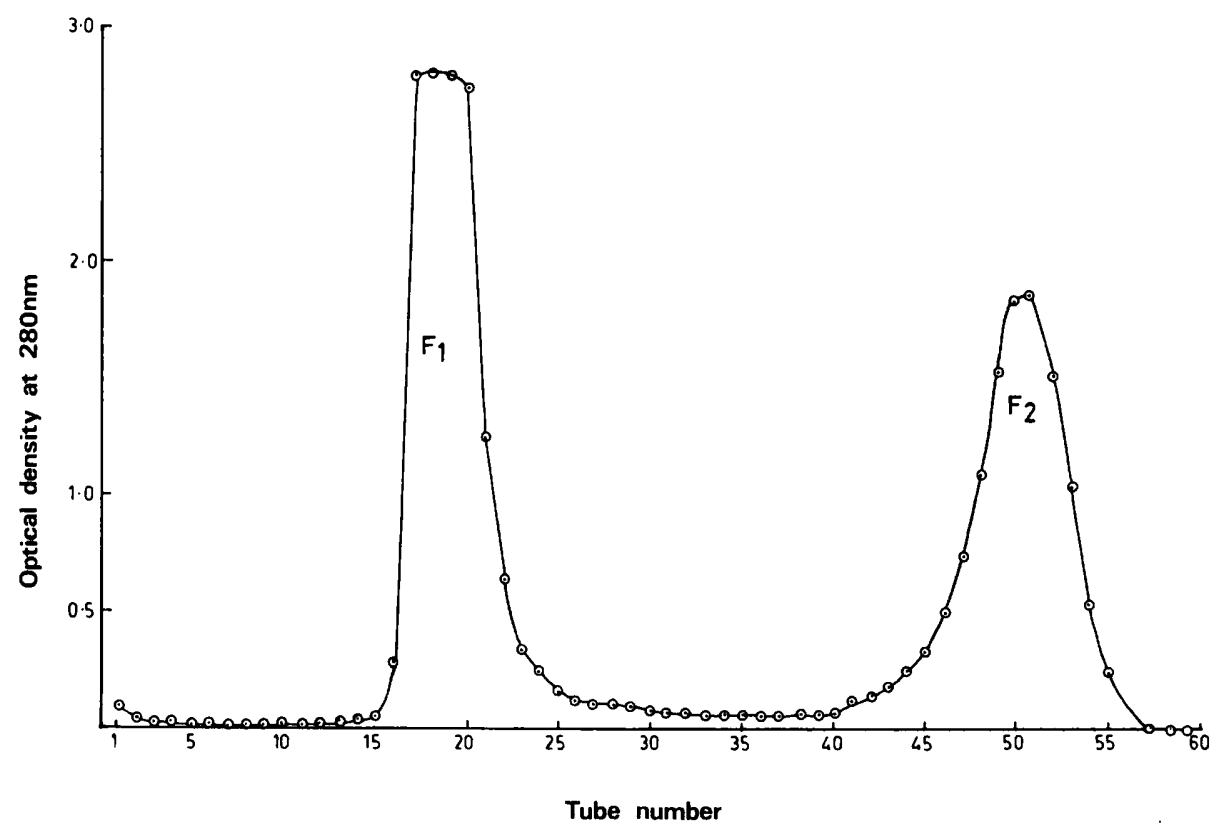

FIG. 1.-Elution profile of crude cytoplasmic protein fraction (CPF) on Sephadex G-200 column; $F_{1}$ and $F_{2}$ represent two distinct protein fractions.

TABLE

Elution profile of crude protein fraction* on

Sephadex G-200

\begin{tabular}{ccccc}
\hline & & & \multicolumn{2}{c}{ Recovery of protein } \\
\cline { 3 - 5 } $\begin{array}{c}\text { Fraction } \\
\text { number }\end{array}$ & $\begin{array}{c}\text { volume } \\
(\mathrm{ml})\end{array}$ & $\begin{array}{c}\text { Protein } \\
(\mu \mathrm{g} / \mathrm{ml})\end{array}$ & $\begin{array}{c}\text { Amount } \\
(\mathrm{mg})\end{array}$ & $\begin{array}{c}\text { Percentage } \\
\text { of total CPF }\end{array}$ \\
\hline 1 & 36 & 290 & 10.44 & 32.625 \\
2 & 49 & 360 & 17.64 & 55.125 \\
\multicolumn{2}{l}{ Total recovery of protein } & 28.08 & 87.75 \\
\hline
\end{tabular}

* Total of $32 \mathrm{mg}$ protein $(\mathrm{CPF})$ in $4.0 \mathrm{ml}$ was
fractionated.

lines with the homologous antigen in gel diffusion, immunoelectrophoresis and CIE (figs. $3 \mathrm{a}, \mathrm{b}$ ). These antisera also formed multiple precipitation arcs with $\mathrm{F}_{1}$ but only two with $\mathrm{F}_{2}$. Agglutinating antibodies determined by the IHA test showed an increase in geometric mean titre from 844 (range 320-1280) in the first week after immunisation to a maximum of 5120 by 3 weeks after immunisation. The geometric mean titre obtained in the third week after immunisation was significantly higher $(p<0.02)$ than that obtained in the first week (fig. 4). In contrast to the results after immunisation by multiple injections, a single-dose immunisation procedure induced a relatively weak immune response. A significant agglutinating antibody response could not be detected in animals up to 2 weeks after immunisation. 

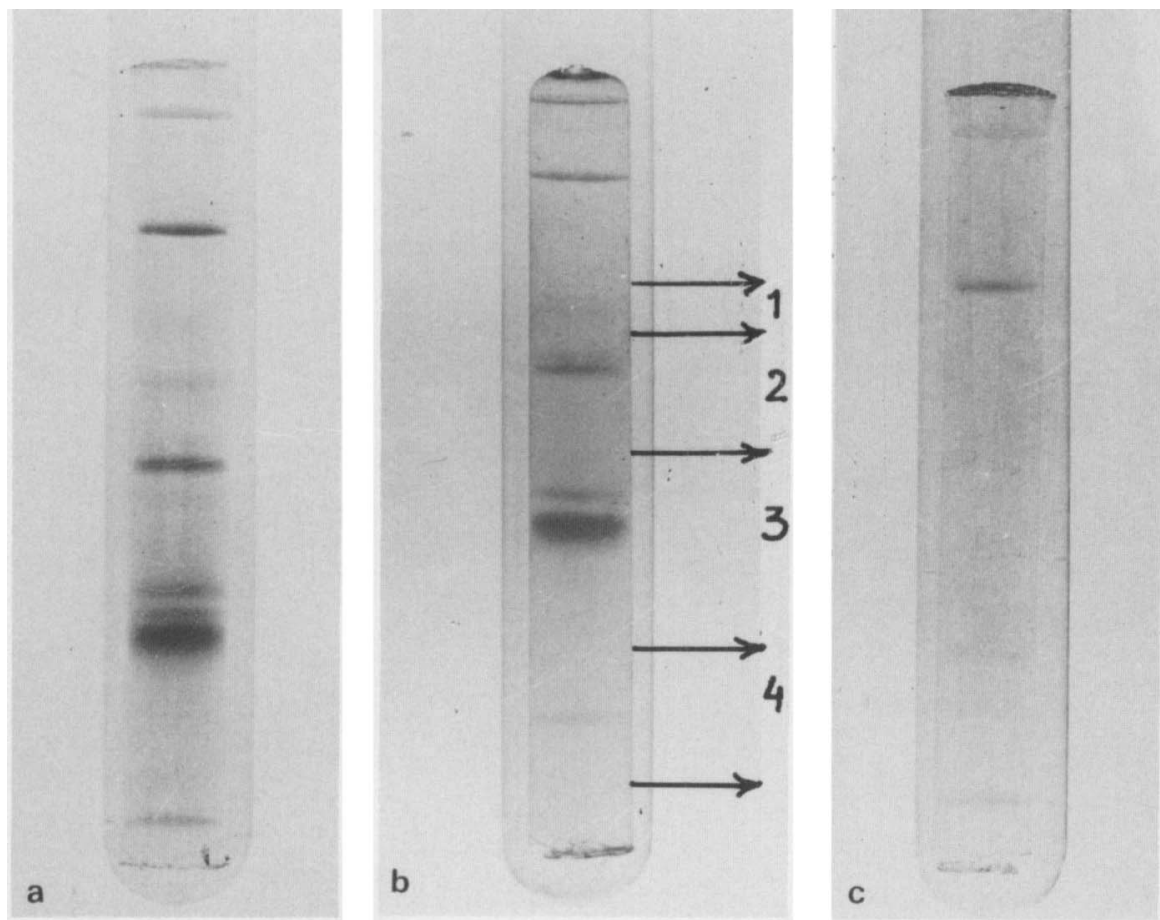

FIG. 2.-Polyacrylamide gel electrophoresis patterns of (a) CPF, (b) $F_{1}$ and (c) $F_{2}$. The arrows indicate the points at which the gels were sliced to obtain different fractions of $F_{1}$ by preparative PAGE.
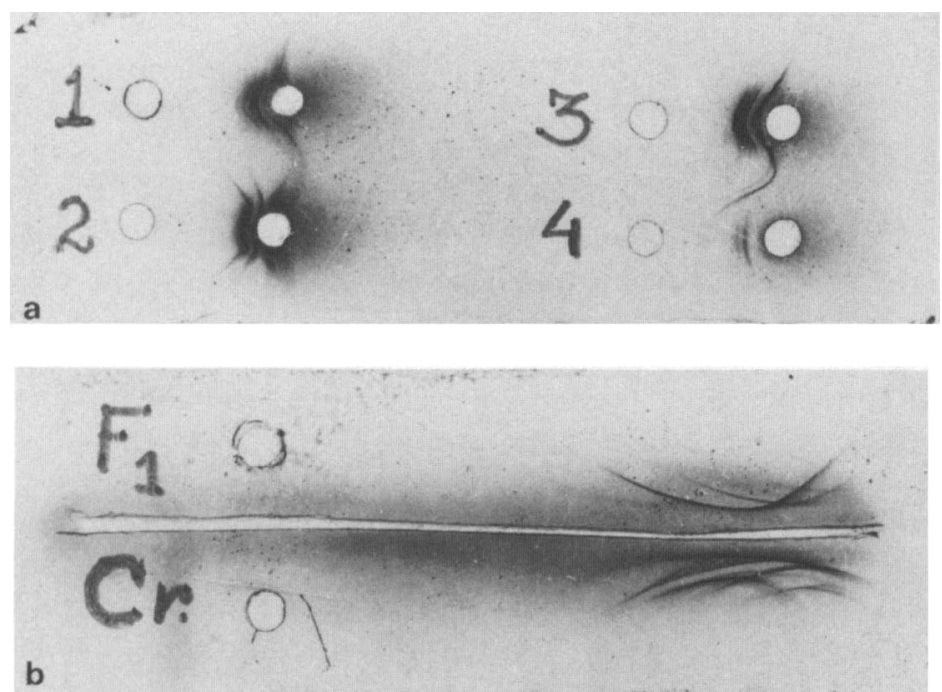

FIG. 3.-(a) Cross reactivity of the antisera raised against CPF demonstrated by CIE with different protein fractions obtained after gel filtration: (1) ammonium sulphate-precipitated CPF; (2) cytoplasmic extract; (3) $F_{1}$, (4) $F_{2}$.

(b) Immunoelectrophoretic patterns of $F_{1}$ and $C P F(C r)$ with antisera raised against CPF. 


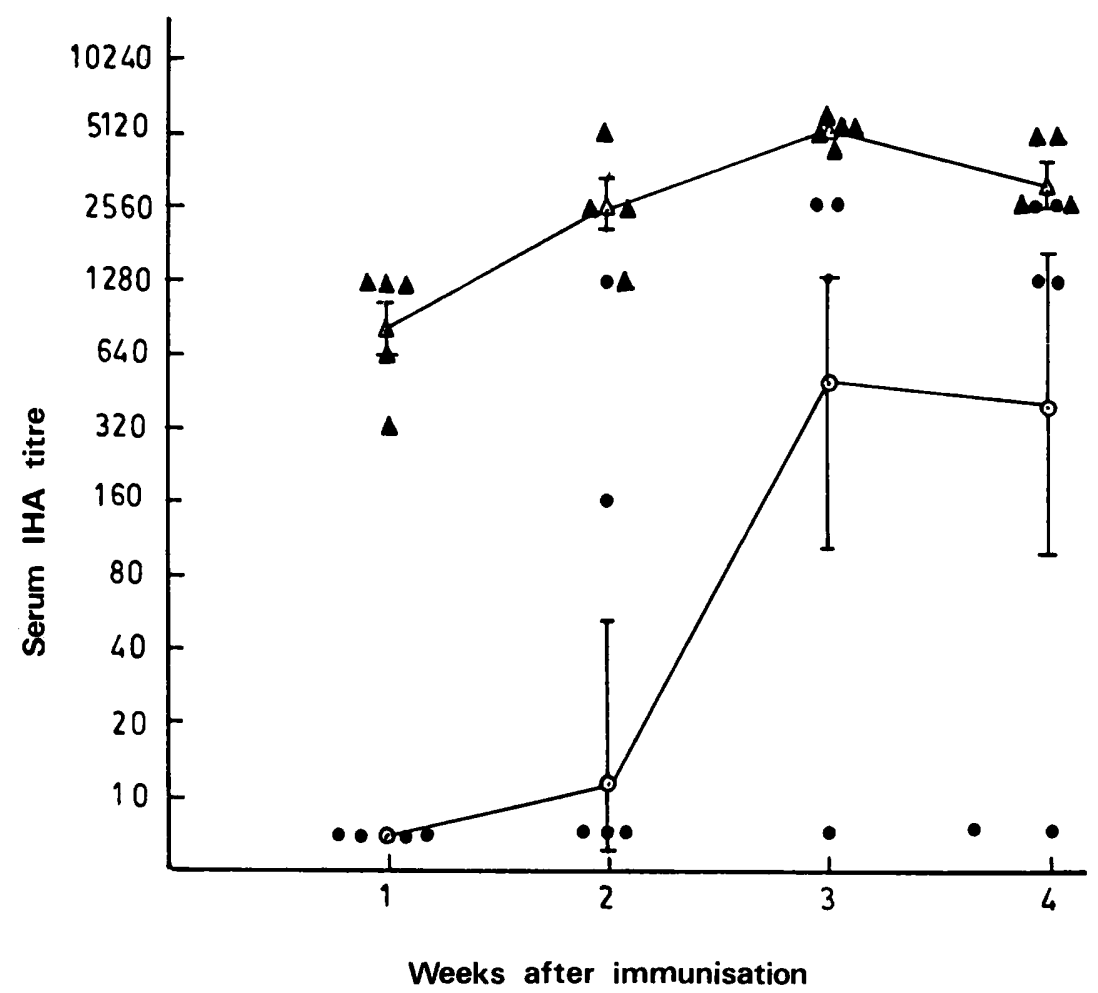

FIG. 4.-Comparison of indirect haemagglutinating titres in mice immunised with single $(\bullet-\bullet)$ and multiple $(\Delta-\Delta)$ doses of CPF. Vertical bars represent the standard error of the geometric mean.

The cellular immune response evaluated by LMI showed significant cellular sensitisation (fig. 5). CPF contains $F_{1}$ and $F_{2}$ and the LMI response was seen in the presence of $F_{1}$ and $F_{2}$ separately. A mean migration inhibition of $50 \cdot 11 \pm 10 \cdot 17 \%$ and $44.68 \pm 4.62 \%$ in the presence of $F_{1}$ and $F_{2}$ respectively was obtained in the first week after immunisation. The maximum cellular sensitisation with $F_{1}$ was seen 2 weeks after immunisation $(65.09 \pm 4.5 \%)$. A similar type of LMI was obtained with $F_{2}$ but the extent of migration inhibition was less than with $F_{1}$. With the single-dose immunisation procedure, no significant migration inhibition $(\mathrm{p}<0 \cdot 2)$ was seen in the first week after immunisation but after 2 weeks significant migration inhibition $(p<0.001)$ was seen in the presence of $F_{1}$ or $F_{2}$ (fig. 5).

Immunisation with $F_{1}$. Antisera obtained from mice immunised with $F_{1}$ formed multiple precipitation lines with the homologous antigen. The sera obtained from $F_{1}$-immunised animals cross-reacted with $C P F$ but did not cross-react with $F_{2}$. Of the four subfractions of $F_{1}$, three (nos. 2, 3 and 4) cross-reacted with CPF antisera. Maximum agglutinating antibody titre (geometric mean titre 5793) was detected 3 weeks after immunisation (fig. 6) and remained unchanged by 4 weeks.

The maximum LMI of $58 \cdot 32 \pm 7 \cdot 16 \%$ was observed 4 weeks after immunisation. The migration pattern seen 1 week after immunisation and that seen after 4 weeks were essentially the same $(p<0 \cdot 1)$ (fig. 7). 


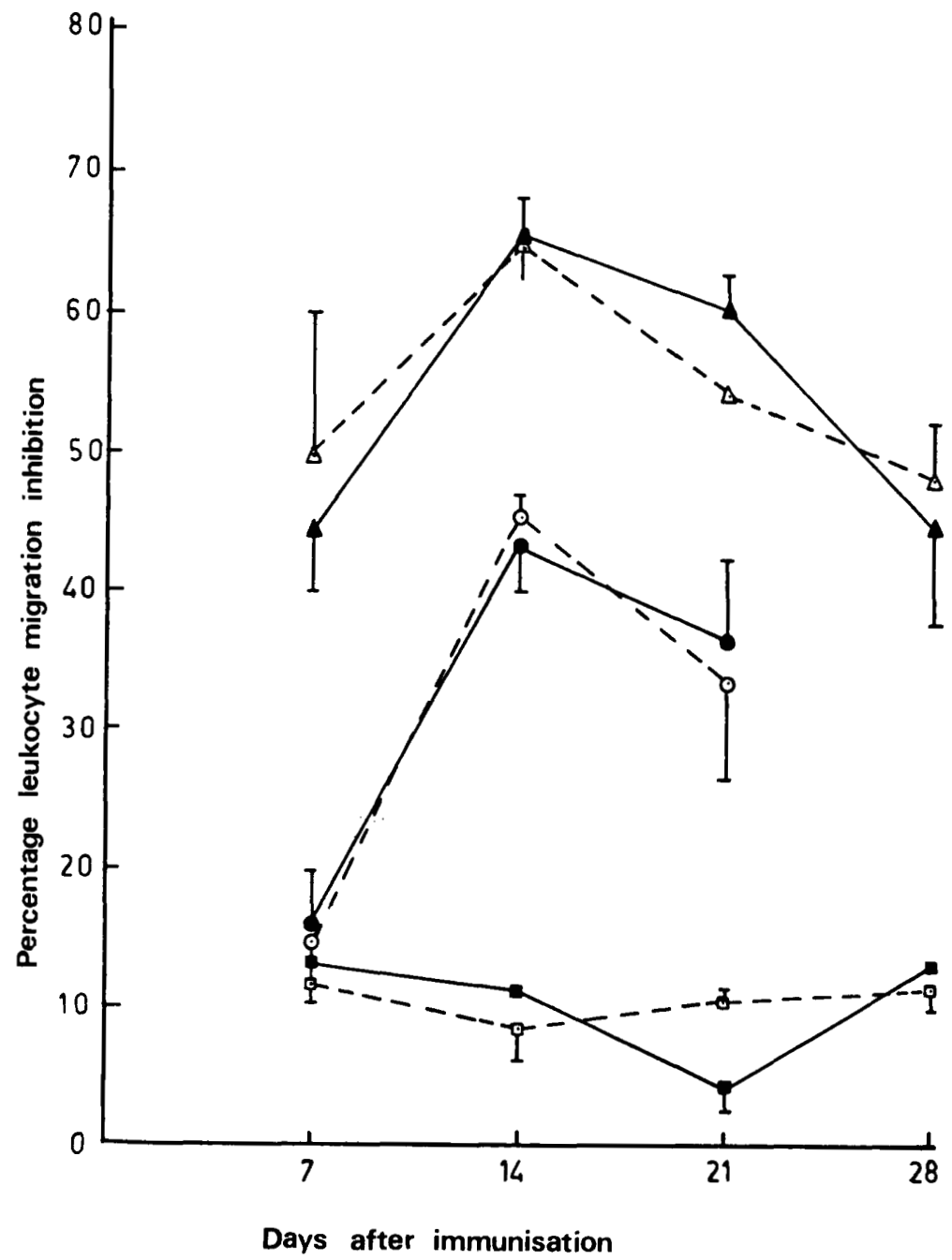

FIG. 5.-Migration inhibition of leukocytes obtained from the mice immunised with single and multiple doses of crude cytoplasmic fraction: $\Delta-\Delta, \Delta \cdots \Delta$ represent the multiple-dose immunization schedule and leukocyte migration inhibition (LMI) in the presence of $F_{1}$ and $F_{2}$ respectively;

O----O represent single-dose immunisation schedule and LMI in the presence of $F_{1}$ and $F_{2}$ respectively; $\square, \square---\square$ represent LMI in control group in the presence of $F_{1}$ and $F_{2}$ respectively. Vertical bars represent the standard errors of the means of the duplicate readings from at least three mice.

Immunisation with $F_{2}$. Induction of immune responses after immunisation with $\mathrm{F}_{2}$ was tested up to 4 weeks, but neither precipitating nor agglutinating antibodies were detected. The percentage LMI values were $<20 \%$ in the presence of the homologous antigen. Thus, immunisation with $\mathrm{F}_{2}$ protein did not induce either humoral or cellular immune responses.

Immunisation with PS I and PS II. The immunogenicity of PS I and PS II was studied with three different immunisation schedules. Precipitating or agglutinating antibodies were not detected up to 4 weeks after immunisation with any of the three 


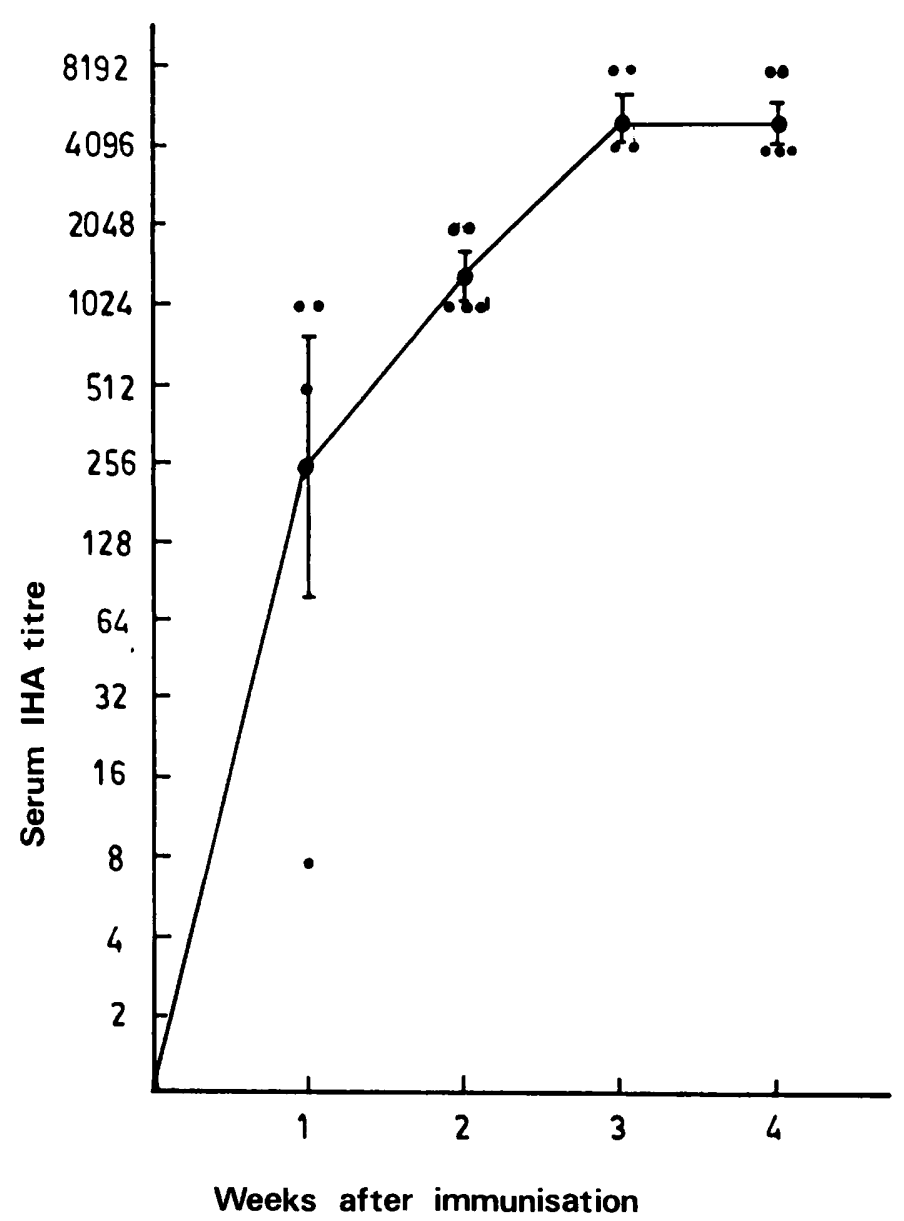

FIG. 6.- Indirect serum haemagglutinating antibody titre in mice immunised with $F_{1}$. Vertical bars represent standard errors of the geometric means obtained from 5 or 6 sera.

schedules. Moreover, there was no significant leukocyte migration inhibition $(\leqslant 20 \%)$ in immunised mice in the presence of homologous antigens.

Immunisation with total phospholipids. Precipitating antibodies against the homologous phospholipid antigen were detected from 1 week after immunisation with total phospholipids. However, these antibodies did not form precipitation lines with purified phosphatidylethanolamine (PE) or cardiolipin (CL) and were specific for the phosphatidylinositol-mannosides (PIM) fraction. The titres or agglutinating antibodies determined by the Kaolin agglutination test are shown in fig. 8 . The agglutinating titres obtained up to the fourth week after immunisation varied from 320 to 1280 .

Immunisation with phospholipids failed to elicit a significant CMI response even after 4 weeks.

\section{Discussion}

Reports on the immunological activities of the various components of $N$. asteroides and their role in the pathogenesis of the disease are lacking, although various protein 


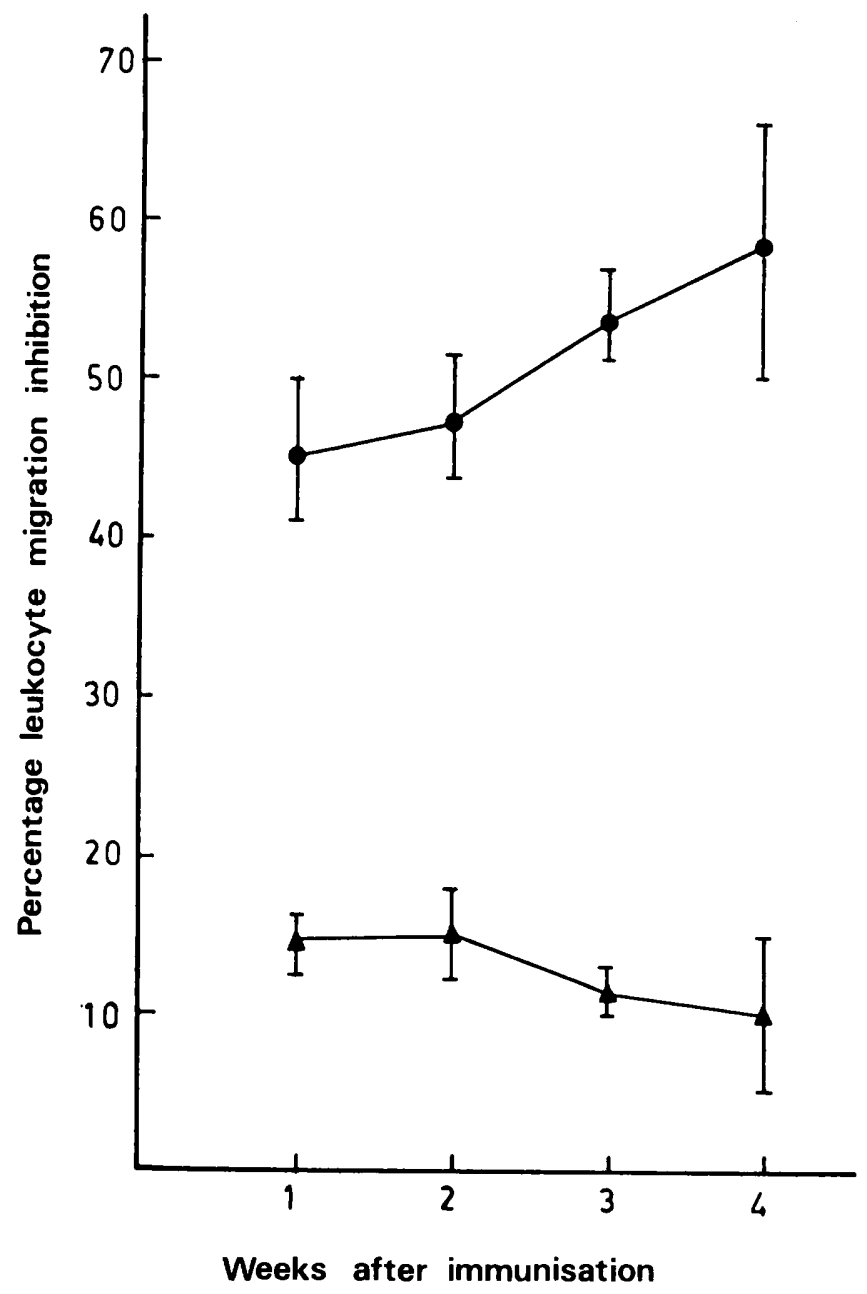

FIG. 7.-Migration inhibition of leukocytes obtained from mice immunised with $F_{1}: \Delta-\Delta$ represents the control group; - represents the immunised group. Vertical bars represent the standard errors of the means of duplicate readings from at least three mice.

(Palmer et al., 1974; Shainhouse et al., 1978; Blumer and Kaufman, 1979) and polysaccharide (Ortiz-Ortiz et al., 1972) fractions from cultural filtrates and whole-cell extracts have been tested for use in diagnostic serology. In the present investigation, the proteins of $N$. asteroides elicited humoral and cellular responses. Lipids elicited only a humoral response whereas polysaccharides were not immunogenic.

Because the aim of the present study was to select immunologically active components with potential for use as immunoprophylactic agents, harsh physicochemical treatment of the bacteria, which may denature many of the proteins, was avoided. Acetone-killed cells were preferred for the isolation of protein antigens because this treatment carries relatively little risk of protein denaturation (Daniel and Janicki, 1978). Polyacrylamide-gel electrophoresis showed that the cytoplasmic protein fraction contained at least eight major protein bands. Although the exact mol. 


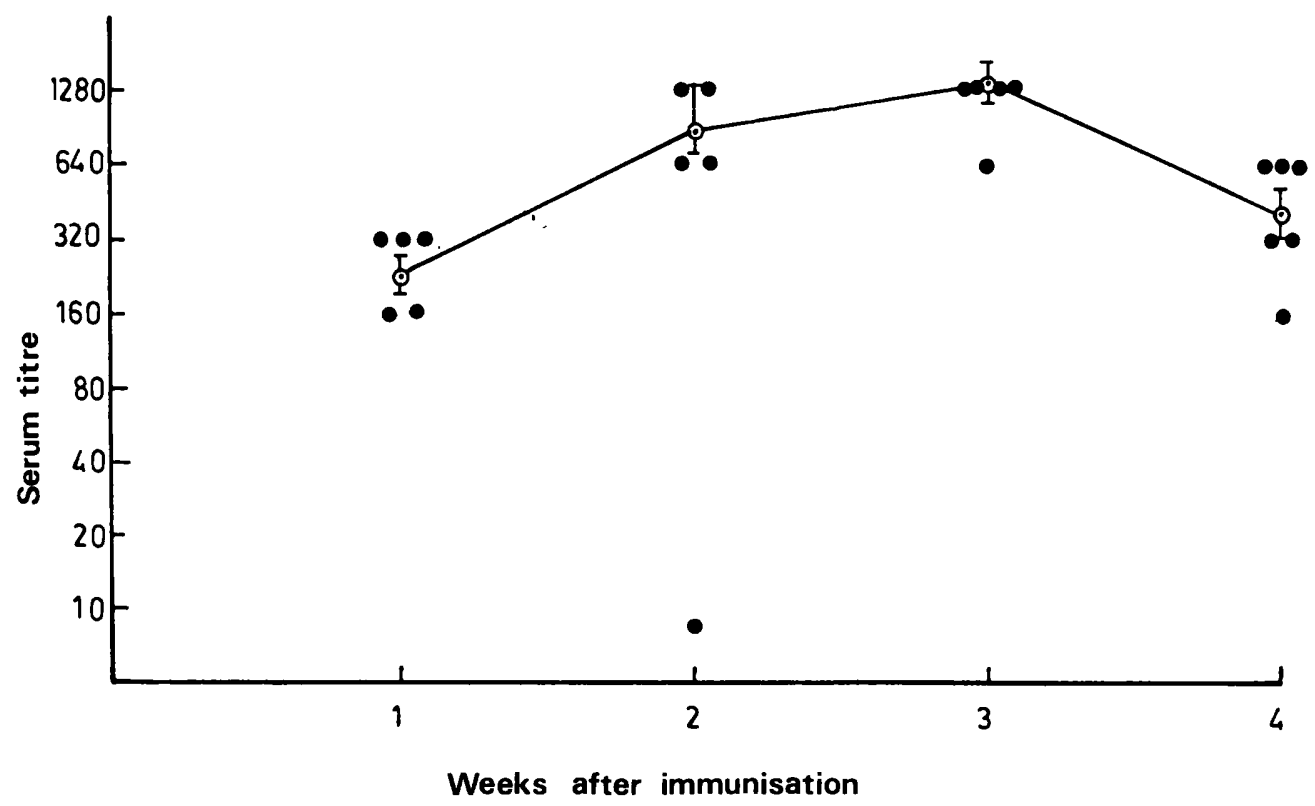

FIG. 8.-Kaolin agglutinating antibody titre of sera from mice immunised with total phospholipid. Vertical bars represent the standard errors of the geometric means of 5 or 6 sera.

wts of the $F_{1}$ and $F_{2}$ fractions were not determined, their elution volumes (Ve) indicated that the mol. wt of $F_{1}$ was $c .50000$ (Ve close to $V o$ ) whereas $F_{2}$ was a low-mol. wt fraction with a Ve close to the bed volume $\left(V_{t}\right)$. Furthermore, the electrophoretic patterns indicated that $F_{1}$ was more complex than $F_{2}$. Preparative PAGE fraction 1 of $F_{1}$ was nonantigenic; it did not form precipitin line with antisera raised against $F_{1}$. Although $F_{2}$ formed two precipitin lines with antisera raised against CPF, when used alone it did not induce an immunological response. This suggests that $F_{2}$ might act as a hapten which serves as an antigen when combined with a carrier protein such as $F_{1}$. The failure of $F_{2}$ to induce an immunological response may be attributed to either its low mol. wt or its structure. In contrast to $F_{2}, F_{1}$ induced a humoral as well as a cellular response as early as one week after immunisation. Use of an RNA-protein complex has been shown to induce cell-mediated immunity up to 70 days after immunisation in guinea pigs (Sundararaj and Agarwal, 1977), although it failed to elicit a humoral immune response.

Neither polysaccharide fraction elicited an immune response, even after selecting three different schedules of immunisation. Nocardial polysaccharide antigens have been investigated by Bojalil and Zamora (1963) for the diagnosis of mycetoma. The spleen cells from animals immunised with whole cells showed the production of MIF in the presence of homologous antigen (Ortiz-Ortiz et al., 1972). The failure of purified polysaccharide fractions to elicit an immune response and the observation that precipitins could be detected against the same PS fractions in animals immunised with formalin-killed Nocardia (data not given) strongly suggested that these polysaccharides might be acting as haptens. An identical observation has been made with the closely related Mycobacterium tuberculosis (Boyden, 1956). The tuberculo-polysac- 
charides are not themselves immunogenic although antigenicity is restored when they are conjugated with proteins or peptides. Our polysaccharide fractions were not completely free of contaminating proteins or peptides, but the treatment of the cells before extraction seem to have at least denatured them.

We have shown that the phospholipids of $N$. asteroides are antigenically similar to the mycobacterial phospholipids which are reported to elicit precipitating, agglutinating and complement-fixing antibodies (Khuller and Subrahmanyam, 1971). Furthermore, the antibodies raised against the total phospholipids did not cross-react with the PE and CL fractions but reacted only with PIM. Thus the PIM of $N$. asteroides is the only immunoreactive phospholipid as has also been found in mycobacteria (Khuller and Subrahmanyam, 1971; Banerjee and Subrahmanyam, 1978).

In contrast to the humoral response, CMI against lipid antigen was not detected. Although lipid-A of LPS, its synthetic analogs and related compounds have been shown recently to exhibit various immunological activities, including a cell-mediating immune response (Kotani et al., 1983), the immunological role of phospholipids has not been investigated extensively. In view of the reports that the phospholipids of mycobacteria and Nocardia cross-react (Khuller and Chopra, 1983) and phospholipids are protective in nature (Khuller et al., 1983), further studies on the immunological basis of the protective mechanism mediated by phospholipids are indicated.

From the present findings, it may be concluded that the protein antigens, especially the $F_{1}$ fraction, of $N$. asteroides show promise as active immunogens for prophylaxis and for the specific diagnosis of systemic or pulmonary nocardiosis.

This study was financed by the Indian Council of Medical Research, New Delhi, India.

\section{REFERENCES}

Banerjee B, Subrahmanyam D 1978 Antigenicity of the phosphatidyl inositomannosides of Mycobacteria. Immunochemistry 15:359-363.

Bartlett G R 1959 Phosphorus assay in column chromatography. Journal of Biological Chemistry 234:466-468.

Beaman B L, Gershwin M E, Ahmed A, Scates S M, Deem R 1982 Response of CBA/N $\mathrm{xDBA} 2 / \mathrm{F}_{1}$ mice to Nocardia asteroides. Infection and Immunity 35:111-116.

Beaman B L, Maslan S 1977 Effect of cyclophosphamide on experimental Nocardia asteroides infection in mice. Infection and Immunity 16:995-1004.

Blumer S O, Kaufman L 1979 Microimmunodiffusion test for nocardiosis. Journal of Clinical Microbiology 10:308-312.

Bojalil L F, Zamora A 1963 Precipitin and skin tests in the diagnosis of mycetoma due to Nocardia brasiliensis. Proceedings of the Society for Experimental Biology and Medicine 113:40-43.

Boyden S V 1956 Antigens of Mycobacterium tuberculosis. Advances in Tuberculosis Research 7:17-51.

Curry W A 1980 Human nocardiosis: A clinical review with selected case reports. Archives of Internal Medicine 140:818-826.

Daniel T M, Janicki B W 1978 Mycobacterial antigens: a review of their isolation, chemistry and immunological properties. Microbiological Reviews 42:84-113.

Davis B J 1964 Disc electrophoresis II. Method and application to human serum proteins. Annals of the New York Academy of Sciences 121:404-427.

Deem R L, Beaman B L, Gershwin M E 1982 Adoptive transfer of immunity to Nocardia asteroides in nude mice. Infection and Immunity 38:914-920. 
Dubois M, Gilles K A, Hemilton J K, Rebers P A, Smith F 1956 Colorimetric method for determination of sugars and related substances. Analytical Chemistry 28:350-356.

Falk R E, Zabriskie J B 1971 The capillary technique for measurement of inhibition of leucocyte migration. An assessment of cell-mediated immunity. In: Bloom B R, Glade P R (eds) In vitro methods in cell-mediated immunity, Academic Press, New York, pp 301-306.

Folch J, Lees M, Sloane-Stanley G H 1957 A simple method for the isolation and purification of total lipids from animal tissues. Journal of Biological Chemistry 226:497-509.

Herbert W J 1978 Passive haemagglutination wth special reference to the tanned cell technique. In: Weir D M (ed) Handbook of experimental immunology, 3rd edn, chapter 20, Blackwell, Oxford.

Hiramine C, Hojo K, Yano I 1981 Development of cell-mediated hypersensitivity in guinea pigs following infection with Nocardia asteroides. International Archives of Allergy and Applied Immunology 65:220-234.

Khuller G K 1976 The mannophosphoinositides of Nocardia asteroides. Experientia 32:1371-1372.

Khuller G K, Chopra A 1983 Mannophosphoinositides of actinomycetales. Actinomycetes 17:22-49.

Khuller G K, Penumarti N, Subrahmanyam D 1983 Induction of resistance to tuberculosis in guinea pigs with mannophosphoinositides of mycobacteria. IRCS Medical Science 11:288-289.

Khuller G K, Subrahmanyam D 1971 Antigenicity of phosphatidyl inositomannosides of Mycobacterium tuberculosis. Immunochemistry 8:251-256.

Kotani S et al 1983 Immunobiological activities of synthetic lipid A analogs and related compounds as compared with those of bacterial lipopolysaccharide, re-glycolipid, lipid A and muramyl dipeptide. Infection and Immunity 41:758-773.

Krick J A, Remington J S 1975 Resistance to infection with Nocardia asteroides. Journal of Infectious Diseases 131:665-672.

Lowry O H, Rosebrough N J, Farr A L, Randall R J 1951 Protein measurement with Folin phenol reagent. Journal of Biological Chemistry 193:265-275.

Ortiz-Ortiz L, Bojalil L F, Contreras M F 1972 Delayed hypersensitivity to polysaccharides from Nocardia. Journal of Immunology 108:1409-1413.

Palmer D L, Harvey R L, Wheeler J K 1974 Diagnosis and therapeutic considerations in Nocardia asteroides infection. Medicine (Baltimore) 53:391-401.

Shainhouse J Z, Pier A C, Stevens D A 1978 Complement fixation antibody test for human nocardiosis. Journal of Clinical Microbiology 8:516-519.

Sundararaj T, Agarwal S C 1977 Cell-mediated immunity to Nocardia asteroides induced by its ribonucleic acid protein fraction. Infection and Immunity 18:253-256.

Takahashi Y 1962 Specific serum agglutination of Kaolin particles sensitized with tubercle phosphatide and its clinical evaluation as a serodiagnostic test for tuberculosis. American Review of Respiratory Diseases 85:708-719.

Zamora A, Bojalil L F, Bastarrachea F 1963 Immunologically active polysaccharides from Nocardia asteroides and Nocardia brasiliensis. Journal of Bacteriology 85:549-555. 